\title{
Fish assemblages on artificial and natural reefs in the Flower Garden Banks National Marine Sanctuary, USA
}

\author{
J. R. Rooker ${ }^{1}$, Q. R. Dokken ${ }^{2}$, C. V. Pattengill ${ }^{3}$, G. J. Holt ${ }^{1}$ \\ ${ }^{1}$ The University of Texas at Austin, Marine Science Institute, 750 Channelview Drive, Port Aransas, Texas 78373, USA \\ ${ }^{2}$ Center for Coastal Studies, Texas A\&M University-Corpus Christi, 6300 Ocean Drive, Corpus Christi, Texas 78412, USA \\ ${ }^{3}$ Department of Biology, Texas A\&M University, College Station, Texas 77843, USA
}

Accepted: 1 August 1996

\begin{abstract}
Visual censusing was used to characterize fish assemblages on artificial and natural reefs located within the boundaries of the Flower Garden Banks National Marine Sanctuary (FGBNMS) in the northwestern Gulf of Mexico. Emphasis was placed on determining spatial and temporal patterns in habitat utilization by fishes on an offshore artificial reef (Mobil Platform HI-A389A). Overall, 43 species were observed during diurnal surveys in the upper $24 \mathrm{~m}$ of the artificial reef. Midwater pelagic fishes (i.e., carangids and scombrids) accounted for over $50 \%$ of all taxa enumerated on the artificial reef; however, these taxa were transient members of the assemblage and were observed infrequently. Labrids, pomacentrids, and serranids were the dominant reef-dependent taxa. Distinct trends in vertical, diel, and seasonal abundances were observed for juvenile and adult fishes. Of the three designated depth zones (upper 1.5-9.0, middle 9.0-16.5; lower 16.5-24.0 m), abundance and species diversity were lowest in the upper zone. Nocturnal counts were characterized by a marked reduction or complete absence of most species, due in part to twilight cover-seeking and movement activities. Seasonal variation in community composition and species abundance (May versus September) was primarily due to recruitment of juveniles (0-age fishes) to the artificial reef in late summer. Increases in total fish abundance (all taxa combined) coincided with both increasing habitat rugosity and degree of fouling. Species richness on natural coral reefs in the FGBNMS was higher than on the artificial reef. Unlike the artificial reef, fish assemblages on the natural reefs were dominated by a single family (Pomacentridae) which accounted for over $50 \%$ of all individuals observed.
\end{abstract}

\section{Introduction}

The presence of a tropical ichthyofaunal component in the northwestern Gulf of Mexico has long been

Correspondence to: J. R. Rooker recognized (e.g., Bright and Cashman 1974; Dennis and Bright 1988). Tropical fish assemblages in this region exhibit elements of the Caribbean reef biota and their distribution is likely to be limited by the scarcity of coral reefs and suitable hard bottom habitats. In the northwestern Gulf of Mexico, these habitats are typically found offshore, exposed to tropical-subtropical, warm, clear oceanic waters (Rezak et al. 1985).

In addition to natural coral reef and hard bank habitats, the abundant offshore petroleum production platforms in the Gulf (ca. 3800; Dokken 1993) serve as habitat for reef fish assemblages (Hastings et al. 1976; Gallaway and Lewbel 1982; Seaman et al. 1989). These structures provide hard substrata which may increase the supply of prey, shelter, and settlement habitat for recruits. Apart from generalized biological descriptions, very little is understood about these artificial fish habitats, particularly with regard to the ecological role of offshore platforms.

Production platforms located near the continental shelf margin of the Gulf of Mexico provide a unique opportunity to expand marine research on tropical fishes associated with offshore artificial and natural habitats. Of particular value is Mobil Production Platform High Island (HI) A-389A which is located within the boundaries of the Flower Garden Banks National Marine Sanctuary (FGBNMS). The sanctuary encompasses the northernmost thriving tropical coral reefs on the continental shelf of North America (Rezak et al. 1985). As a result, fish assemblages located in this area are unique, combining tropical reef-dependent and offshore pelagic fish species.

The purpose of this study was to determine spatial and temporal patterns in habitat utilization by juvenile (0agerecruits) and adult fishes occupying an offshore production platform. Emphasis was placed on determining vertical distribution, diel periodicity, and seasonal variation in abundance of reef inhabitants. Microhabitat selection (i.e., effect of substrate complexity) was also investigated. Quantitative surveys from the East and West Flower Garden Banks (EFG and WFG) were conducted for comparisons of natural and artificial reef fish assemblages. 


\section{Materials and methods}

\section{Study area}

The study was conducted on artificial and natural reefs within the boundaries of the FGBNMS, approximately 110 miles $(177 \mathrm{~km}) \mathrm{SE}$ of Galveston, Texas (Fig. 1). Efforts were concentrated on platform HI-A389A $\left(27^{\circ} 54^{\prime} 30^{\prime \prime} \mathrm{N}, 93^{\circ} 35^{\prime} 06^{\prime \prime} \mathrm{W}\right)$, located in $125 \mathrm{~m}$ of water, and approximately $2 \mathrm{~km}$ and $22 \mathrm{~km}$ from the high diversity reef zones at the EFG and WFG, respectively. Submerged reefs atop the EFG and WFG, which crest at approximately $17-20 \mathrm{~m}$, are dominated by Montastrea annularis, Diploria strigosa, Colpophyllia spp., and Porites astreoides. At similar depths, the platform is dominated by sponges (ca. $>80 \%$ of fouling community) (Adams 1995), with minimal coral cover provided primarily by the fire coral Millepora alcicornis. Desmacella meliorata, Tedania ignis, Stelleta kallitetilla, and Neofibularia nolitangere accounted for the majority of the sponge cover above $40 \mathrm{~m}$.

\section{Sampling methods}

Visual censusing was used to investigate patterns in habitat utilization on the artificial reef. Censusing was conducted on linear transects by paired divers using SCUBA. Diver 1 swam $1 \mathrm{~m}$ above the transect line and enumerated all fishes encountered within $1 \mathrm{~m}$ of the transect on each side $(1 \mathrm{~m}$ height $\times 2 \mathrm{~m}$ width), while diver 2 recorded all midwater fishes out to $5 \mathrm{~m}$ on each side and $5 \mathrm{~m}$ above. Since diver 1 and 2 censused separate areas, the two counts were combined. Fish were categorized by life stage (i.e., juvenile and intermediate/adult) based on size and life-stage specific coloration patterns. Counts were tabulated on underwater slates.

Twenty-seven $10 \mathrm{~m}$ transects were marked on diagonal jacket members (structural framework of platform) at three different depth zones $(9$ transects per depth zone): $1.5-9.0 \mathrm{~m}, 9.0-16.5 \mathrm{~m}$, $16.5-24.0 \mathrm{~m}$. Surface waters $(<1.5 \mathrm{~m})$ were not surveyed due to strong surges which complicated visual enumeration. Moreover, deeper regions of the platform $(24.0-52.0 \mathrm{~m})$ were surveyed qualitatively due to bottom-time restrictions. Inherent sampling problems associated with using horizontal and vertical jacket members as transects (e.g., horizontal: restricted depth zonation; vertical: variable jacket diameter) were avoided by basing transects on diagonal jacket members only. Preliminary visual counts of fishes on diagonal, horizontal, and vertical jacket members were conducted and no significant differences (ANOVA, $P>0.05$ ) in abundance or diversity were detected.

To facilitate comparisons between artificial and natural reef fish assemblages, quantitative surveys of the EFG and WFG were taken during September 1994. Repetitive stationary diver censuses, as described by Bohnsack and Bannerot (1986), were used for natural reef surveys. These enumerations were based on visual counts within a cylinder $6.5 \mathrm{~m}$ in radius and $4 \mathrm{~m}$ in height. At each sampling point, species within the cylinder dimensions were listed during a $5 \mathrm{~min}$ period; statistical data (e.g., number, ontogenetic stage) were recorded after the $5 \mathrm{~min}$ period. Species present during the initial 5 min, but not during the enumeration period, were also recorded. Cylinders were positioned randomly using both a random compass heading and number of fin kicks. The number of stationary visual counts completed during the September sampling period at the EFG and WFG was 24 and 21, respectively. All visual counts were taken near the reef crest (ca. 18-25 m) between 1000-1600 h.

The primary seasonal trend in fish abundance in the northwestern Gulf of Mexico is related to changes in water temperature and photoperiod which potentially serve as cues for spawning. McGowan (1985) reported that the peak larval fish abundance for many taxa occurs from spring to early fall at the FGBNMS, when water temperatures were highest. Consequently, sampling was conducted during periods of potentially high recruitment of new juveniles; May 25-30 and September 1-5, 1994. Mean sea temperatures were $24^{\circ} \mathrm{C}$ and $29^{\circ} \mathrm{C}$ in May and September, respectively (1994 annual temperature range: $19^{\circ} \mathrm{C}-29^{\circ} \mathrm{C}$ ). Censuses during each seasonal period were taken between 1000-1600 h. Random sets of transects (set comprised of transects from all three depth zones) were surveyed each day (i.e., 6 or 9 transects per day). All transects (27) were surveyed over a five day period during each season. Qualitative deep water surveys were made over four trips from May to December, 1994.

Differences in fish abundance and distribution between day and night periods were examined during the May 1994 survey. Transects selected each day for diurnal censusing were repeated at night (2000-2200 h). Although lights on the platform provided partial

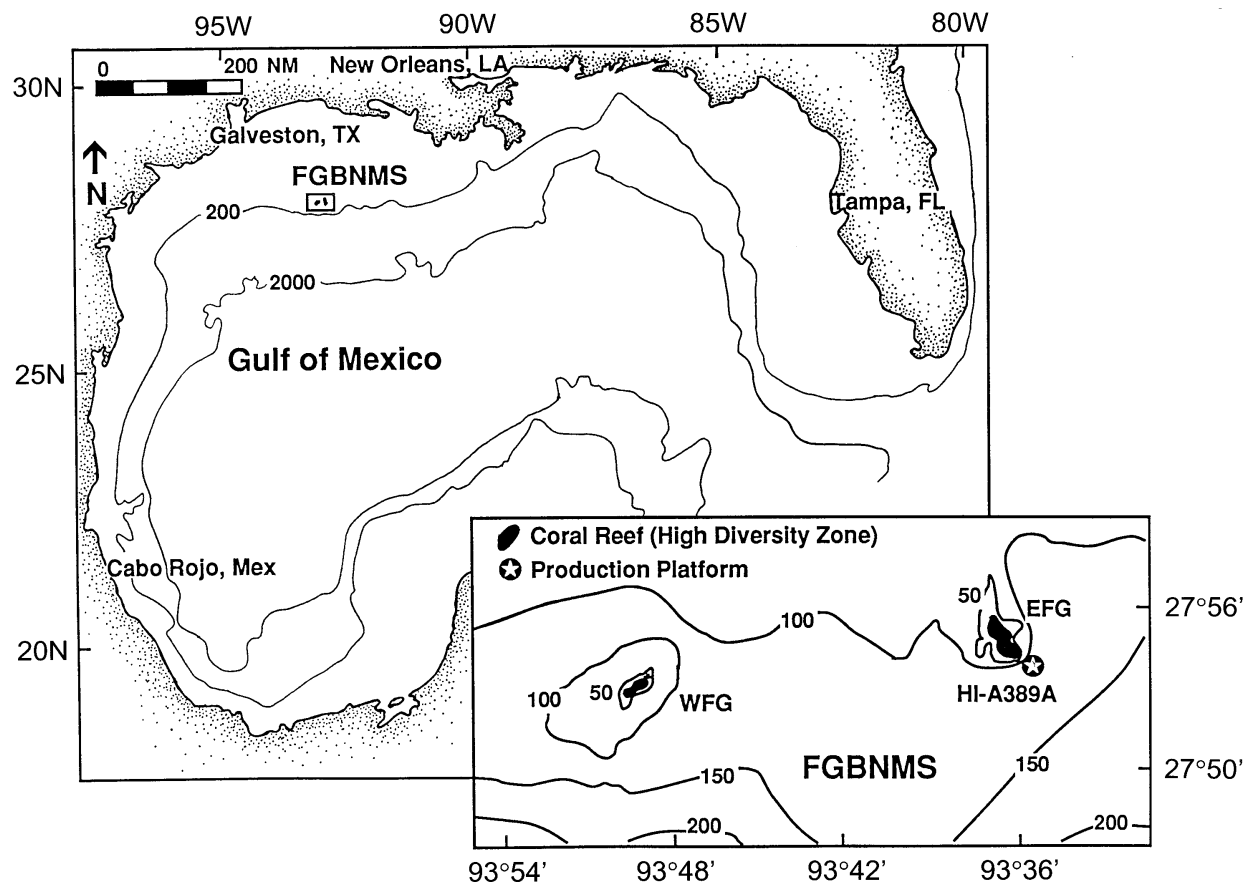

Fig. 1. Map of the study site, showing the location of the Flower Garden Banks National Marine Sanctuary (FGBNMS) in the northwestern Gulf of Mexico. Detailed map indicates the location of Mobil Production Platform High Island A-389A in relation to the East and West Flower Garden Banks (EFG and WFG, respectively). Contour intervals are in meters (m) 
illumination of surface waters (i.e., divers could see silhouettes of fishes), dive lights were necessary during night-time censuses. In addition, preliminary twilight observations were made on September 2-4, 1994, during dusk (1910-2110 h; time of sunset 1944-1946 h) to assist in the explanation of observed day-night changes. Twilight activities were recorded by two divers with each diver observing activities at different localities on the platform. Information recorded during the sunset observations included the chronological sequence of species present and their behavioral activities (i.e., cover-seeking and movement).

The relationship between substrate complexity and fish abundance was evaluated during September 1994. Surface rugosity (defined here as contour distance of substrate divided by the straight line distance) and degree of fouling (defined here as straight line circumference of jacket divided by the circumference of bare jacket member) were measured using techniques similar to McClanahan and Shafir (1990) and Chandler et al. (1985). Rugosity was measured using a weighted line and contouring the substrate along a $1 \mathrm{~m}$ straight line distance. Degree of fouling was determined by measuring the straight line circumference of the platform jacket relative to the circumference of the bare jacket (no fouling). Substrate complexity measures and fish abundance estimates were taken concurrently at 20 randomly selected $1 \mathrm{~m}$ quadrats in the middle depth zone $(9.0-16.5 \mathrm{~m})$ of the platform. At each point, $1 \mathrm{~m}$ sections were marked on diagonal jacket members and all fishes within the quadrat were counted. After visual enumerations were completed, substrate complexity was assessed. Estimates of rugosity and degree of fouling were determined as mean values based on three measures from each quadrat.

Fish without distinctive coloration or those closely resembling other species could only be tentatively identified. To avoid errors in identification, adults of Stegastes variabilis, S. fuscus, and S. planifrons were lumped together as Stegastes spp. However, juveniles were easily distinguished by coloration and were identified to species. Therefore, S. variabilis, S. fuscus, and S. planifrons refer to juveniles only; Stegastes spp. denotes adults. Adults of the only other congener ( $S$. partitus) could be positively identified.

Visual census methodology is often biased (Sale and Douglas 1981; Brock 1982; Sale and Sharp 1983; Bortone and Kimmel 1991). Potential bias in this study was largely due to variations in the visibility of fishes in the censused areas. Small, cryptic species are easily missed (Green and Alevizon 1989). These species (e.g., blenniids, gobiids) may hide in the substrate leading to underestimates of density. Time of day or light levels also influence visibility. Although light levels were fairly constant among diurnal sampling periods, bias may be present in day-night comparisons. Night-time visibility was limited to some degree, though the dive light illuminated a section of the jacket similar in area to the field of vision observed during the day. Water clarity was excellent during the entire study (horizontal visibility ca. $30 \mathrm{~m}$ ) and, consequently, bias associated with variable clarity was minimal.

\section{Data analysis}

Species-specific abundance data were statistically analyzed with a repeated measures analysis of variance (ANOVA) (Winer 1971). The effects of depth and season were investigated using a two-way repeated measures ANOVA. In addition, a one-way repeated measures ANOVA was used to investigate diel periodicity on species distribution, with time of day as the main effect. ANOVA results were further examined with Tukey's honestly significant difference (HSD) method to determine which levels of the main effect(s) differed significantly $(\alpha=0.05)$ from other levels. Statistical testing was limited to taxa present in moderate to high abundances. This designation included taxa observed at a mean abundance (all diurnal counts combined) equal to or greater than 0.05 individuals $\mathrm{m}^{-2}$ substrate ( $n=17$ taxa) and appeared to represent a natural division. Due to insufficient sample sizes, taxa present in limited numbers $(<0.05$ individuals $\mathrm{m}^{-2}$ substrate) were not analyzed statistically. Moreover, transient members of the reef fish assemblage (i.e., carangids, scombrids) were not evaluated statistically. Data were log-transformed prior to testing to minimize heteroscedasticity.

To examine patterns in ecological diversity on artificial and natural reefs, Shannon diversity $\left(H^{\prime}\right)$ and evenness $\left(J^{\prime}\right)$ indices were calculated (Magurran 1988). The Shannon diversity index $\left(H^{\prime}\right)$ was estimated as

$H^{\prime}=-\sum p_{i} \ln p_{i}$

where $p_{i}$ is the proportion of the total number of individuals occurring in species $i$. Evenness $\left(J^{\prime}\right)$ was calculated as

$J^{\prime}=H^{\prime} / \ln S$

where $S$ is the total number of species.

\section{Results}

\section{Assemblage composition on the artificial reef}

Overall, 43 species were observed during diurnal surveys in the upper $24 \mathrm{~m}$ of the platform (Table 1). Of the 7171 individuals enumerated, taxa included both pelagic and reef-associated fishes. Midwater pelagic fishes (carangids and scombrids) accounted for over $50 \%$ of all taxa enumerated on the artificial reef. Caranx spp. and Euthynnus alletteratus were the dominant pelagic taxa by number. These taxa were infrequent members of the reef fish assemblage (percent frequency of occurrence ca. 15\%) and often observed in large schools (ca. 500-900). In fact, over 90\% of all carangids and scombrids were observed during surveys of only three transects (ca. 5\% of all transects surveyed). As a result, these transient species were omitted from further quantitative descriptions and not evaluated statistically. By contrast, the dominant reef-associated species $(>70 \%$ frequency of occurrence), in decreasing abundance were Paranthias furcifer, Thalassoma bifasciatum, Stegastes partitus, Ophioblennius atlanticus, Epinephelus adscensionis, Bodianus rufus, and Stegastes variabilis. Apart from midwater activity by Paranthias furcifer and Bodianus rufus, most reef-associated taxa were observed in close proximity $(<0.2 \mathrm{~m})$ to the substrate.

While intermediates to adults were the common ontogenetic stages observed $\left(4.7 \mathrm{~m}^{-2}\right.$ of substrate), juveniles were present in moderate abundance $\left(1.83 \mathrm{~m}^{-2}\right)$. Juveniles were dominated by labrids (Thalassoma bifasciatum, Bodianus rufus, B. pulchellus) and pomacentrids (Stegastes partitus, S. variabilis, S. planifrons, S. fuscus, Abudefduf saxatilis) (Table 1). In addition, juvenile acanthurids, scarids, and serranids were also observed. T. bifasciatum, S. partitus, S. variabilis, and Sparisoma aurofrenatum accounted for $87.1 \%$ of all juveniles. All species present as juveniles (i.e., successful recruits) were also present as intermediates-adults.

\section{Vertical zonation}

The abundance and diversity on the platform were lowest in the upper zone and increased in the two deeper zones. Percentages of total number found in the upper, middle, and lower zones were $23 \%, 30 \%$, and $47 \%$, respectively. Species richness $(S)$ and diversity $\left(H^{\prime}\right)$ were highest in the 
Table 1. Abundance and percent frequency of occurrence (based on transects) of fish taxa inhabiting the artificial reef (HI-A389A) in the FGBNMS during different seasons. Percent of taxa that were juveniles are also shown. Counts based on diurnal surveys conducted in the upper $24 \mathrm{~m}$ of the platform (27 transects per season). Repeated measures ANOVA results given for seasonal comparisons. $N$ number of individuals counted

\begin{tabular}{|c|c|c|c|c|c|c|c|c|}
\hline \multirow[t]{2}{*}{ Species } & \multicolumn{3}{|c|}{ May-94 } & \multicolumn{5}{|c|}{ Sep-94 } \\
\hline & $N$ & $\begin{array}{l}\% \text { Frequency } \\
\text { Occurrence }\end{array}$ & $\begin{array}{l}\% \\
\text { Juveniles }\end{array}$ & $N$ & $\begin{array}{l}\% \text { Frequency } \\
\text { Occurrence }\end{array}$ & $\begin{array}{l}\% \\
\text { Juveniles }\end{array}$ & \multicolumn{2}{|c|}{ Season } \\
\hline Abudefduf saxatilis & 19 & 18.5 & 0.0 & 36 & 44.4 & 55.6 & 8.56 & $* *$ \\
\hline Abudefduf taurus & 3 & 11.1 & 0.0 & 0 & - & - & $\dagger$ & \\
\hline Acanthurus chirurgus & 3 & 11.1 & 0.0 & 0 & - & - & $\dagger$ & \\
\hline Acanthurus coeruleus & 36 & 66.7 & 19.4 & 59 & 96.3 & 1.7 & 8.54 & $* *$ \\
\hline Aluterus scriptus & 1 & 3.7 & 0.0 & 1 & 3.7 & 0.0 & $\dagger$ & \\
\hline Amblycirrhitus pinos & 6 & 18.5 & 0.0 & 4 & 11.1 & 0.0 & $\dagger$ & \\
\hline Balistes capriscus & 0 & - & - & 11 & 25.9 & 0.0 & $\dagger$ & \\
\hline Bodianus pulchellus & 14 & 14.8 & 0.0 & 23 & 44.4 & 0.0 & 3.27 & ns \\
\hline Bodianus rufus & 61 & 70.4 & 3.3 & 68 & 74.1 & 22.1 & 0.10 & ns \\
\hline Cantherhines macrocerus & 2 & 3.7 & 0.0 & 3 & 11.1 & 0.0 & $\dagger$ & \\
\hline Cantherhines pullus & 11 & 29.6 & 0.0 & 7 & 22.2 & 0.0 & $\dagger$ & \\
\hline Caranx crysos & 405 & 14.8 & 0.0 & 2140 & 14.8 & 0.0 & $\dagger$ & \\
\hline Caranx hippos & 172 & 18.5 & 0.0 & 15 & 14.8 & 0.0 & $\dagger$ & \\
\hline Caranx ruber & 1 & 3.7 & 0.0 & 18 & 18.5 & 0.0 & $\dagger$ & \\
\hline Chaetodon sedentarius & 8 & 18.5 & 0.0 & 7 & 18.5 & 0.0 & $\dagger$ & \\
\hline Chromis multilineata & 22 & 25.9 & 90.9 & 21 & 14.8 & 52.4 & 0.51 & ns \\
\hline Clepticus parrae & 3 & 7.4 & 0.0 & 1 & 3.7 & 0.0 & $\dagger$ & \\
\hline Diodon hystrix & 2 & 7.4 & 0.0 & 4 & 11.1 & 0.0 & $\dagger$ & \\
\hline Elagatis bipinnulata & 0 & - & - & 45 & 7.4 & 0.0 & $\dagger$ & \\
\hline Epinephelus adscensionis & 65 & 74.1 & 0.0 & 106 & 100.0 & 0.0 & 14.52 & $* *$ \\
\hline Epinephelus cruentatus & 0 & - & - & 2 & 3.7 & 0.0 & $\dagger$ & \\
\hline Euthynnus alletteratus & 0 & - & - & 900 & 3.7 & 0.0 & $\dagger$ & \\
\hline Holacanthus bermudensis & 4 & 14.8 & 0.0 & 0 & - & - & $\dagger$ & \\
\hline Holacanthus ciliaris & 1 & 3.7 & 0.0 & 4 & 11.1 & 0.0 & $\dagger$ & \\
\hline Holocentrus marianus & 1 & 3.7 & 0.0 & 3 & 11.1 & 0.0 & $\dagger$ & \\
\hline Hypsoblennius invemar & 9 & 11.1 & 0.0 & 3 & 7.4 & 0.0 & $\dagger$ & \\
\hline Kyphosus sectatrix & 374 & 44.4 & 0.0 & 33 & 40.7 & 0.0 & 4.73 & $*$ \\
\hline Melichthys niger & 1 & 3.7 & 0.0 & 2 & 7.4 & 0.0 & $\dagger$ & \\
\hline Ophioblennius atlanticus & 77 & 77.8 & 0.0 & 113 & 88.9 & 0.0 & 3.91 & ns \\
\hline Parablennius marmoreus & 30 & 51.8 & 0.0 & 15 & 40.7 & 0.0 & 2.93 & ns \\
\hline Paranthias furcifer & 696 & 59.3 & 0.1 & 337 & 81.5 & 1.8 & 2.86 & ns \\
\hline Seriola dumerili & 3 & 7.4 & 0.0 & 3 & 7.4 & 0.0 & $\dagger$ & \\
\hline Sparisoma aurofrenatum & 5 & 11.1 & 40.0 & 107 & 70.4 & 89.7 & 20.40 & $* *$ \\
\hline Sparisoma viride & 0 & - & - & 2 & 7.4 & 100.0 & $\dagger$ & \\
\hline Sphyraena barracuda & 18 & 40.7 & 0.0 & 9 & 25.9 & 0.0 & 1.97 & ns \\
\hline Stegastes spp. & 23 & 44.4 & 0.0 & 34 & 55.6 & 0.0 & 0.21 & ns \\
\hline Stegastes fuscus & 1 & 3.7 & 100.0 & 22 & 55.6 & 100.0 & $\dagger$ & \\
\hline Stegastes partitus & 51 & 59.3 & 54.9 & 172 & 70.4 & 86.6 & 23.41 & $* *$ \\
\hline Stegastes planifrons & 3 & 7.4 & 100.0 & 2 & 7.4 & 100.0 & $\dagger$ & \\
\hline Stegastes variabilis & 21 & 37.0 & 100.0 & 130 & 81.5 & 100.0 & 63.17 & $* *$ \\
\hline Thalassoma bifasciatum & 158 & 74.1 & 84.3 & 344 & 88.9 & 89.5 & 29.57 & $* *$ \\
\hline Total number of fishes & 2344 & & & 4827 & & & & \\
\hline Total number of juveniles & 217 & & & 769 & & & & \\
\hline Total number of taxa & 38 & & & 39 & & & & \\
\hline
\end{tabular}

*, ** significant at $P<0.05$ and $P<0.01$, respectively. ns: not significant $(P>0.05)$

${ }^{\dagger}$ not analyzed statistically due to low abundance. Carangids and scombrids also excluded

Stegastes spp. not counted as separate taxa

middle depth zone (Table 2). Although $S$ was lowest in the upper zone, evenness $\left(J^{\prime}\right)$ was highest.

Species-specific patterns in vertical distribution were also observed in the upper reaches of the platform $(24 \mathrm{~m})$. Figure 2 depicts vertical profiles for selected taxa $(n=17)$ in the three zones $(1.5-9.0 \mathrm{~m}, 9.0-16.5 \mathrm{~m}, 16.5-24.0 \mathrm{~m})$. Significant $(P<0.05)$ differences in vertical zonation were identified for 13 taxa using a repeated measures ANOVA. Abudefduf saxatilis, Ophioblennius atlanticus, and Sphyraena barracuda were most abundant in the 
shallowest depth stratum. Conversely, 10 taxa were rarely observed in the upper depth zone: Bodianus pulchellus, B. rufus, Chromis multilineata, Parablennius marmoreus, Paranthias furcifer, Sparisoma aurofrenatum, Stegastes spp., S. variabilis, S. partitus and Thalassoma bifasciatum. No significant variation in abundance with depth $(P>0.05)$ was observed for Acanthurus coeruleus, $C$. multilineata, Canthigaster rostrata, Epinephelus adscensionis. Pairwise comparisons using Tukey's HSD test showed results in accordance with these findings (Fig. 2).

At depths ranging from $24.0-52.0 \mathrm{~m}$, only three of the above taxa, Abudefduf saxatilis, Ophioblennius atlanticus, and Kyphosus sectatrix were not observed. Sphyraena barracuda was observed between 24.0 and $38.0 \mathrm{~m}$, but not deeper. Seven additional species, not present above

Table 2. Species richness $(S)$, Shannon diversity $\left(H^{\prime}\right)$ and evenness $\left(J^{\prime}\right)$ indices for artificial and natural reefs in the FGBNMS. Diversity estimations are based on diurnal counts from September 1994. $N$ represents the number of transects (artificial reef) or stationary visual counts (natural reefs)

\begin{tabular}{lrrrrl}
\hline & $N$ & $S$ & $H^{\prime}$ & $J^{\prime}$ & $\begin{array}{c}\text { Number of } \\
\text { individuals }\end{array}$ \\
\hline Artificial reef & & & & & \\
HI-A389A & 27 & 39 & 2.411 & 0.630 & $1706^{\dagger}$ \\
$\quad$ Upper & 9 & 27 & 2.151 & 0.660 & 269 \\
$\quad$ Middle & 9 & 38 & 2.331 & 0.641 & 596 \\
$\quad$ Lower & 9 & 37 & 2.028 & 0.562 & 841 \\
Natural reefs & & & & & \\
EFG & 24 & 59 & 2.230 & 0.547 & 3163 \\
WFG & 21 & 54 & 2.429 & 0.596 & 2870 \\
\hline
\end{tabular}

$\dagger$ excludes carangids and scombrids $(n=3121)$
$24.0 \mathrm{~m}$, were observed in deeper regions of the platform (24.0-52.0 m): Chromis cyanea, C. enchrysurus, C. insolata, C. scotti, Chaetodon aya, Centropyge argi, and $M y$ cteroperca rubra. Moreover, a conspicuous pattern in vertical distribution was observed for Microspathodon chrysurus which showed a significant increase in abundance below $24 \mathrm{~m}$.

\section{Day-night variability}

Nocturnal counts (2000-2200 h) on the artificial reef were characterized by marked declines or complete absence of diurnally-observed species (Table 3). Significant $(P<0.05)$ nocturnal declines were observed for 15 taxa: Abudefduf saxatilis, Acanthurus coeruleus, Bodianus pulchellus, B. rufus, Canthigaster rostrata, Chromis multilineata, Ophioblennius atlanticus, Parablennius marmoreus, Paranthias furcifer, Sphyraena barracuda, Stegastes spp., S. partitus, $S$. variabilis, Thalassoma bifasciatum, and juveniles (all taxa combined). No significant $(P>0.05)$ diel changes were observed for Epinephelus adscensionis and Kyphosus sectatrix. Abudefduf taurus and Gymnothorax moringa showed increases in nocturnal abundance. However, limited numbers $(<10$ individuals) precluded statistical testing of these species. One additional species, Carcharhinus falciformis, was commonly observed during nocturnal counts; however, all individuals were outside the boundaries of the visually censused area ( $>5 \mathrm{~m}$ from observer).

Preliminary observation of twilight activity indicated that nocturnal reductions in abundance were partly due to two behaviors: cover-seeking and movement. Most species showed cover-seeking behavior at night (Table 3). Smaller species (e.g., pomacentrids, labrids, all juveniles)

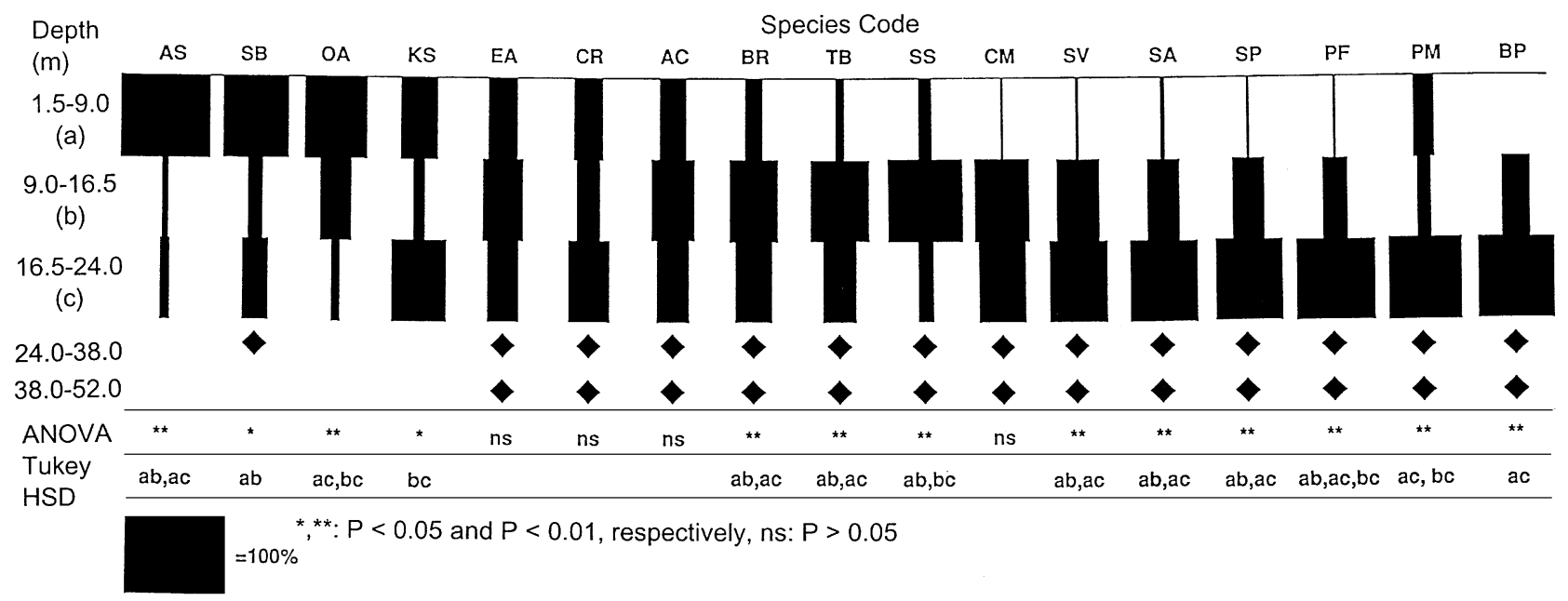

Fig. 2. Relative abundance of selected fish species with depth (upper $24 \mathrm{~m}$ ) expressed as a percentage of the total number of that species. Diamonds indicate the presence of taxa in deeper depth regions: 24-38 $\mathrm{m}$ and $38-52 \mathrm{~m}$. Repeated measures ANOVA and Tukey's HSD test results are given for each taxon. Letters $a, b$, and $c$ represent depths $1.5-9 \mathrm{~m}, 9.0-16.5$, and $16.5-24.0 \mathrm{~m}$, respectively. Paired letters denote significant differences $(P<0.05)$ between depth zones. Taxonomic code: $\mathrm{AS}=$ Abudefduf saxatilis, $\mathrm{SB}=$ Sphyraena barra- cuda, $\mathrm{OA}=$ Ophioblennius atlanticus, $\mathrm{KS}=$ Kyphosus sectatrix, $\mathrm{EA}=$ Epinephelus $\quad$ adscensionis,$\quad \mathrm{CR}=$ Canthigaster rostrata, $\mathrm{AC}=$ Acanthurus coeruleus, $\mathrm{BR}=$ Bodianus rufus, $\mathrm{TB}=$ Thalassoma bifasciatum, $\mathrm{SS}=$ Stegastes spp., $\mathrm{CM}=$ Chromis multilineata, $\mathrm{SV}=$ Stegastes $\quad$ variabilis, $\quad \mathrm{SA}=$ Sparisoma aurofrenatum, $\mathrm{SP}=$ Stegastes partitus, $\mathrm{PF}=$ Paranthias furcifer, $\mathrm{PM}=$ Parablennius marmoreus, $\mathrm{BP}=$ Bodianus pulchellus 
Table 3. Day-night changes in abundance of selected taxa on the artificial reef (HI-A389A). Estimates of abundance based on individuals per $\mathrm{m}^{-2}$ of substrate. Diel comparisons based or counts taken in May 1994. Differences in number of individuals between diel periods were determined using a repeated measures ANOVA. Observations of nocturnal behaviors are also noted

\begin{tabular}{lllrrll}
\hline Taxa & $\begin{array}{l}\text { Day } \\
\text { Ind./m2 }\end{array}$ & $\begin{array}{l}\text { Night } \\
\text { Ind./m2 }\end{array}$ & MS & F & P & $\begin{array}{l}\text { Nocturnal } \\
\text { Behavior }\end{array}$ \\
\hline Abudefduf saxatilis & 0.07 & 0.00 & 0.75 & 4.98 & $*$ & CS \\
Acanthurus coeruleus & 0.13 & 0.04 & 2.80 & 16.80 & $* *$ & CS \\
Bodianus pulchellus & 0.05 & 0.00 & 0.59 & 4.13 & $*$ & CS \\
Bodianus rufus & 0.23 & 0.01 & 9.90 & 44.73 & $* *$ & CS \\
Canthigaster rostrata & 0.09 & 0.00 & 3.90 & 41.77 & $* *$ & CS \\
Chromis multilineata & 0.08 & 0.00 & 1.22 & 6.09 & $*$ & CS \\
Epinephelus adscensionis & 0.24 & 0.15 & 0.35 & 1.65 & $\mathrm{~ns}$ & - \\
Kyphosus sectatrix & 1.39 & 3.72 & 6.76 & 2.66 & $\mathrm{~ns}$ & $\mathrm{M}$ \\
Ophioblennius atlanticus & 0.29 & 0.00 & 15.72 & 76.08 & $* *$ & CS \\
Parablennius marmoreus & 0.11 & 0.00 & 5.21 & 23.03 & $* *$ & - \\
Paranthias furcifer & 2.58 & 0.31 & 9.01 & 11.85 & $* *$ & CS \\
Sphyraena barracuda & 0.07 & 0.00 & 1.87 & 17.19 & $* *$ & M \\
Stegastes spp. & 0.09 & 0.05 & 4.29 & 0.05 & $*$ & CS \\
Stegastes partitus & 0.19 & 0.00 & 7.65 & 39.84 & $* *$ & CS \\
Stegastes variabilis & 0.08 & 0.00 & 1.91 & 14.02 & $* *$ & CS \\
Thalassoma bifasciatum & 0.59 & 0.00 & 30.46 & 208.26 & $* *$ & CS \\
Juveniles (all species) & 0.77 & 0.00 & 49.66 & 192.87 & $* *$ & CS \\
\hline
\end{tabular}

*, ** significant $(P<0.05$ and $P<0.01$, respectively). ns: not significant $(P>0.05)$ Observed nocturnal behaviors: cover-seeking (CS), movement $(\mathrm{M})$, no changes in behavior observed (-) sought shelter in the refuge provided by the fouling community. Visual observations of these species were not possible after cover-seeking activity. Larger individuals, such as intermediate-adult Balistes capriscus, Bodianus pulchellus, B. rufus, Clepticus parrae, and Paranthias furcifer, also sought cover in the fouling community, particularly in sponge crevices. However, due to the limited size of refuges provided by the fouling community, these larger fishes ( $>15 \mathrm{~cm}$ total length) were often incompletely concealed, with their caudal fin outside the cover provided by sponges. Such individuals were included in nocturnal counts. Movement activities were also observed for certain species; however, this behavior was not as obvious as cover-seeking. While Sphyraena barracuda appeared to move away from the platform at night, large schools of Kyphosus sectatrix moved to the interior of the jacket structure after sunset.

\section{Seasonal changes}

Seasonal variation in composition and abundance of the artificial reef assemblage was observed between the May and September surveys (Table 1). Of the 17 species analyzed, eight $(47 \%)$ showed significant differences $(P<0.05)$ in seasonal abundance: Acanthurus coeruleus, Epinephelus adscensionis, Kyphosus sectatrix, Sparisoma aurofrenatum, Thalassoma bifasciatum, and a suite of territorial damselfishes including Abudefduf saxatilis, Stegastes partitus, and S. variabilis. Peak abundances for these species occurred during September when significant numbers of juvenile recruits were present. Juveniles of all taxa (excluding carangids and scombrids), accounted for $12.3 \%$ and $44.7 \%$ in May and September, respectively. The abundance of juveniles was $0.80 \mathrm{~m}^{-2}$ of substrate and 2.85 $\mathrm{m}^{-2}$ in May and September, respectively. Species showing a stable seasonal pattern $(P>0.05)$ showed little or no recruitment of juveniles.

\section{Microhabitat selection}

Substrate complexity (rugosity, degree of fouling) was significantly correlated with the abundance of reef fishes on the platform. Marked increases in total fish abundance (all taxa combined) occurred with both increasing rugosity and degree of fouling (Fig. 3). Linear regressions of both measures of substrate complexity on fish abundance $(N)$ were significant $(P<0.01)$ and described by the equations: $\quad N=-48.429+47.710 \cdot R \quad\left(r^{2}=0.73\right) \quad$ and $N=-39.412+37.313 \cdot F\left(r^{2}=0.66\right)$, where $R$ and $F$ represent rugosity and degree of fouling, respectively. The predictive power of the relationship between substrate complexity and abundance was enhanced when both rugosity and degree of fouling were examined simultaneously. A multiple regression model incorporating both predictor variables was significant $(P<0.01)$ and explained over $83 \%$ of the variability in fish abundance. Rugosity and degree of fouling were also associated with number of fish species $(S)$. Similar to findings observed for abundance, a positive relationship between substrate complexity and number of species was observed $(P<0.05)$. Coefficients of determination for regressions based on rugosity and degree of fouling were 0.36 and 0.37 , respectively.

\section{Comparisons to natural coral reefs}

Overall, species richness and relative abundance (based on percent composition by number) of reef-dependent taxa on the EFG and WFG differed from the artificial reef. Species richness estimates were higher on the natural reefs, even though evenness $\left(J^{\prime}\right)$ and Shannon diversity $\left(H^{\prime}\right)$ were relatively similar (Table 2). Unlike the artificial reef fish assemblage which was dominated by midwater carangids and scombrids, assemblages on the EFG and WFG were comprised primarily of reef-dependent taxa (99\%) and 

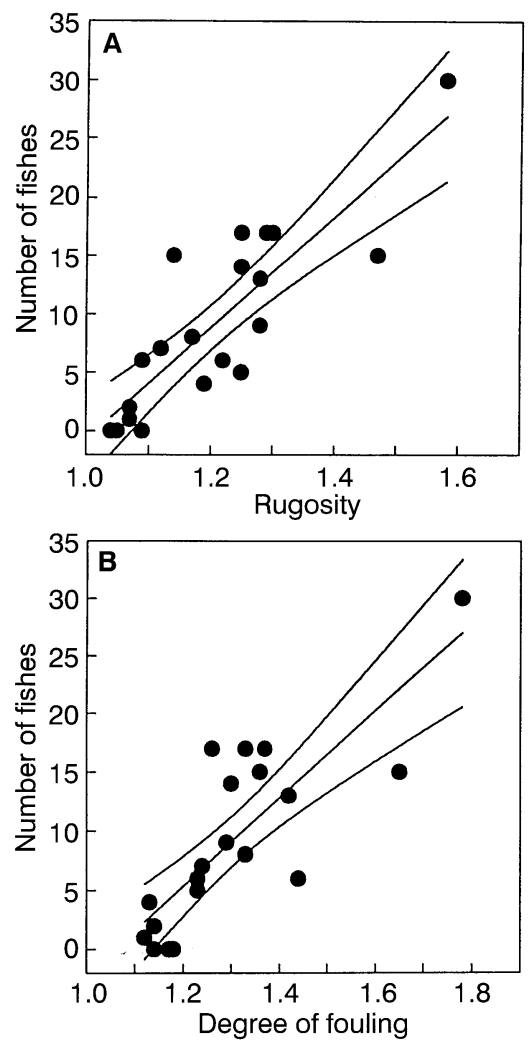

Fig. 3A-B. Relationships between substrate complexity and fish abundance. Two measures of substrate complexity are described: A rugosity and $\mathbf{B}$ degree of fouling. Linear regression plots include $95 \%$ confidence intervals

Table 4. Percent composition by number estimates for fish taxa associated with artificial (HI-A389A) and natural (EFG and WGB) reefs in the FGBNMS. Estimates for artificial and natural reefs based on counts from the September 1994 survey

\begin{tabular}{|c|c|c|c|}
\hline \multirow[t]{2}{*}{ Family } & \multicolumn{2}{|c|}{ Natural reefs } & \multirow{2}{*}{$\frac{\text { Artificial reef }}{\text { HI-A389A }}$} \\
\hline & EFG & WFG & \\
\hline Acanthuridae & 1.0 & 1.0 & 3.7 \\
\hline Balistidae & 0.6 & 0.4 & 1.5 \\
\hline Blenniidae & 0.1 & 0.2 & 8.2 \\
\hline Chaetodontidae & 1.3 & 1.6 & 0.4 \\
\hline Gobiidae & 1.2 & 0.7 & 0.0 \\
\hline Kyphosidae & 0.3 & 5.9 & 2.1 \\
\hline Labridae & 20.2 & 21.5 & 27.1 \\
\hline Pomacentridae & 62.8 & 53.0 & 19.8 \\
\hline Scaridae & 4.6 & 6.9 & 6.8 \\
\hline Serranidae & 3.2 & 3.1 & 27.7 \\
\hline Sphyraenidae & 0.1 & 0.1 & 0.6 \\
\hline Tetradontidae & 2.6 & 3.3 & 1.2 \\
\hline Others taxa & 1.9 & 2.2 & 0.9 \\
\hline Total number of fishes & 3163 & 2870 & $1706^{\dagger}$ \\
\hline Total number of juveniles & 703 & 478 & 769 \\
\hline Time surveyed (h) & 5.6 & 4.9 & 4.5 \\
\hline Areas surveyed $\left(\mathrm{m}^{2}\right)$ & 3168 & 2786 & 2025 \\
\hline
\end{tabular}

${ }^{\dagger}$ excludes carangids and scombrids $(n=3121)$ midwater pelagic species were present in limited numbers $(<1 \%)$.

On both natural and artificial reefs, assemblages (reefdependent) were dominated by a few families (Table 4), principally pomacentrids and labrids. Chromis multilineata and C. cyanea were the dominant pomacentrids on natural reefs, representing $63.2 \%$ and $17.3 \%$ of damselfishes, respectively (Fig. 4). A suite of Stegastes species accounted for the majority of remaining damselfishes. Labrids were also common on natural reefs and accounted for approximately $20 \%$ of all taxa observed on the EFG and WFG. Thalassoma bifasciatum was the most
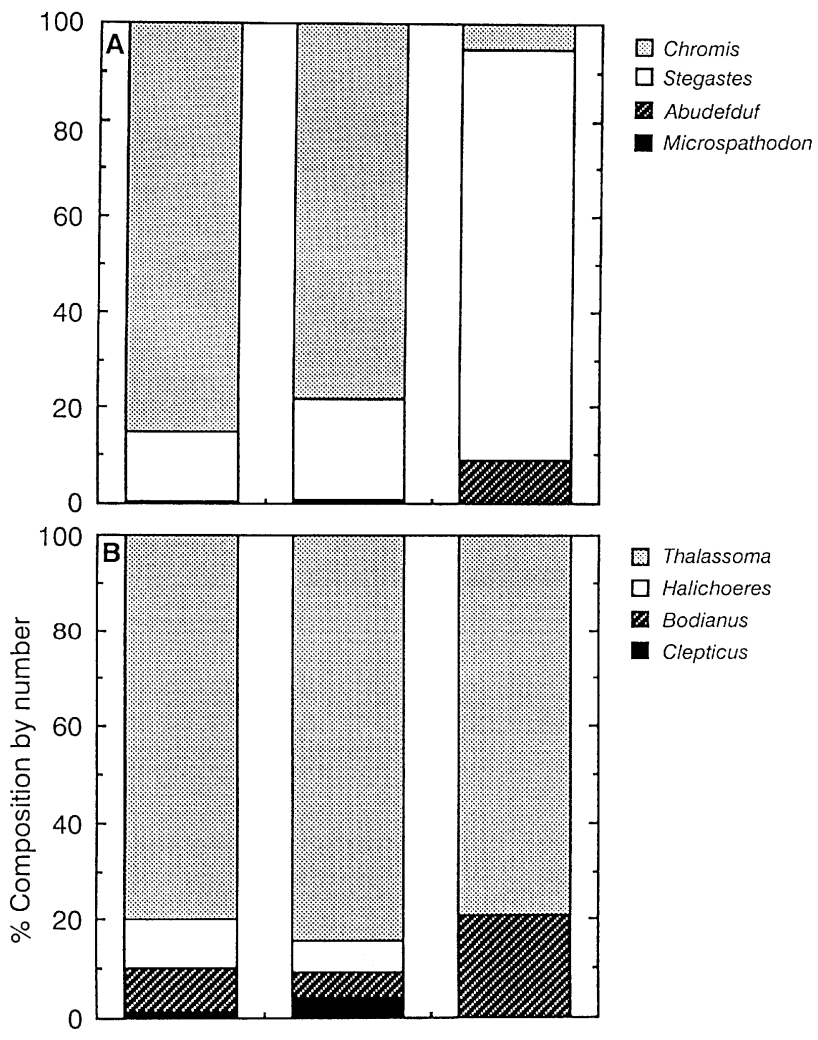

Thalassoma

$\square$ Halichoeres

Bodianus

- Clepticus

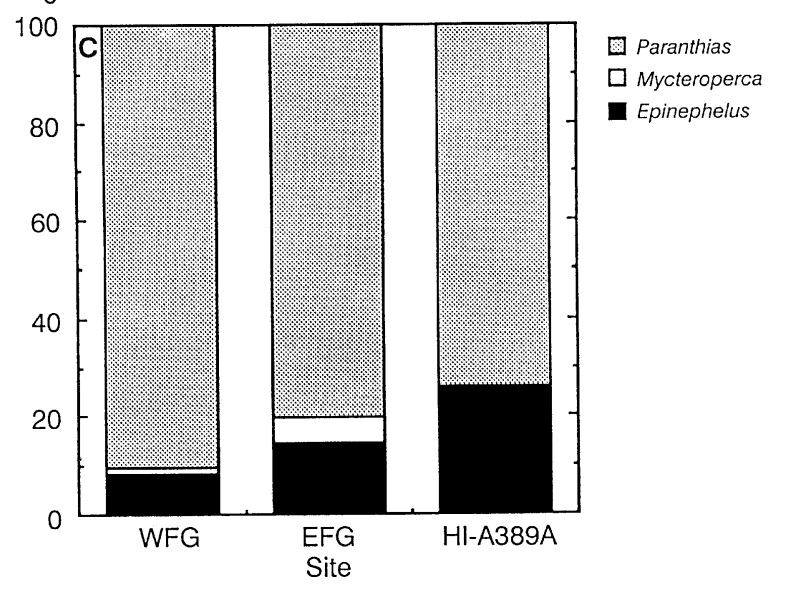

Fig. 4A-C. Taxonomic composition of reef fish assemblages observed on artificial and natural reefs in the FGBNMS. Percent composition by number estimates are given for genera in three primary families: A Pomacentridae, B Labridae, and C Serranidae 
common, representing $84.4 \%$ and $79.8 \%$ of observed labrid taxa at the EFG and WFG, respectively. Bodianus spp. and Halichoeres spp. were less abundant on both natural reefs. Remaining reef fish families observed in moderate numbers on the EFG and WFG included Scaridae, Kyphosidae, Serranidae, Tetradontidae, Chaetodontidae, and Acanthuridae (Table 4).

Unlike natural reef fish assemblages, serranids, labrids, and pomacentrids were equally dominant on the artificial reef. Relative abundance of serranids was higher on the artificial reef than on natural reefs, and roughly equal to that of pomacentrids and labrids (Table 4). Epinephelus adscensionis and Paranthias furcifer accounted for nearly all serranid taxa on the platform (Fig. 4). Paranthias furcifer was relatively more abundant on natural reefs, and an additional serranid taxa (Mycteroperca) was observed more frequently. Similar to the EFG and WFG, labrids on the platform accounted for approximately one quarter of the reef-dependent assemblage and were dominated by Thalassoma bifasciatum; however, the artificial reef maintained higher numbers of Bodianus spp., while Halichoeres spp. were only present on natural reefs. In contrast to natural reef fish assemblages where Chromis spp. was the dominant damselfish taxa, Chromis spp. accounted for only $5 \%$ of damselfishes observed on the platform. Stegastes partitus and S. fuscus comprised over $80 \%$ of observed pomacentrids on the platform. Apart from the addition of blennies, the remaining taxa on the platform were similar to the EFG and WFG.

\section{Discussion}

The artificial reef habitat provided by the platform supports a diverse ichthyofaunal assemblage comprised of both mobile pelagic fishes as well as site-attached fishes. Assemblage composition was similar in some respects to other offshore platforms in the northwest Gulf of Mexico (Gallaway and Lewbel 1982); however, additional coral reef fishes were also present. Despite their numerical dominance, midwater pelagics (i.e., carangids, scombrids) were transient members of the platform community and infrequently observed within the boundaries of the transects. The more permanent members of the community were tropical reef fishes, principally labrids, pomacentrids, and serranids.

The reef fish assemblage on the artificial reef is similar to the faunal composition of adjacent communities, namely the EFG and WFG. Higher numbers of species were observed on the EFG and WFG than the platform. This may be due to the greater habitat complexity and area available on the natural reefs (i.e., positive species-area relationship). McClanahan (1994) reported positive species-area relationships for several coral reef fish families commonly observed in this study (pomacentrids, labrids, scarids). Horizontal areas of reef habitat at the EFG, WFG, and HI-A389A were approximately 0.95, 0.36, and $<0.01 \mathrm{~km}^{-2}$, respectively. Several alternative explanations for higher measures of species richness on the EFG and WFG must also be considered (e.g., differences in habitat diversity, depth-related differences in larval supply, differences in visual sampling effort).
Furthermore, differences could be methods related since only limited portions of the artificial and natural reefs were surveyed. Despite some disparity in the number of species (ca. $25 \%$ reduction on artificial reef), the composition of fish assemblages was similar between natural and artificial habitats. The majority of taxa present in moderate frequencies ( $>25 \%$ frequency of occurrence) at the EFG and WFG were also observed on the platform. Moreover, species showing moderate to high numbers of juveniles ( $>20$ individuals) were observed on both natural and artificial habitats, except for Scarus spp..

Differences in assemblage composition between natural and artificial reefs were observed for certain taxa. Many species of scarids and mullids were relatively common on the natural reefs, but rare or lacking on the artificial reef. It seems likely that this was due to the lack of proper foraging grounds at the platform. Many scarids feed on algae and polyps obtained by scraping the coral matrix or lifting calcareous sand for detritus. Moreover, mullids live in close association with sand or mud bottoms and feed on benthic fauna. No coral matrix or sand bottom habitats exists in the censused zone at the platform and, as a result, foraging requirements of these taxa were not met. Conversely, the relative abundance of some taxa (Abudefduf saxatilis, Ophioblennius atlanticus) was markedly higher on the artificial reef than on the banks. These species are ubiquitous on tropical shallow water reefs (McGehee 1994; Robertson 1988) and the lack of shallow habitat $(<20 \mathrm{~m})$ at the EFG or WFG may preclude their successful recruitment. In fact, $A$. saxatilis has been rarely observed on the EFG and WFG (Dennis and Bright 1988); however, mooring buoys placed on the banks in 1991 have provided enough shallow habitat to support large numbers of juveniles, which in turn appears responsible for the recent arrival of adults on the EFG and WFG.

The species composition on artificial and natural reefs in the FGBNMS is similar to the Caribbean biota. Nevertheless, certain taxa such as snappers (Lutjanidae) and grunts (Haemulidae), which dominate coral reef fish communities $(<50 \mathrm{~m})$ in the tropical Western Atlantic (Randall 1983; Thresher 1991), are rare or absent (excluding deepwater snappers, such as Lutjanus campechanus, which have been observed at $80 \mathrm{~m}$ ). Many juvenile snappers (e.g., Lutjanus spp., Ocyurus chrysurus) and grunts (e.g., Haemulon spp.) utilize seagrass and mangrove habitats as nursery grounds (Ogden and Gladfelter 1983; Rooker and Dennis 1991; Rooker 1995), while the same areas serve as nocturnal foraging habitats for adults (Starck 1971; Collette and Talbot 1972; Hobson 1975; Rooker and Dennis 1991). Since these species have specific requirements during ontogeny, it is reasonable to assume that the lack of necessary habitat in the FGBNMS prevents successful colonization. In addition, nearest resident populations of these primary reef fishes are substantial distances from the FGBNMS (nearest tropical coral reefs: Cabo Rojo, Mexico, $700 \mathrm{~km} \mathrm{SW}$ and Dry Tortugas, USA, $1100 \mathrm{~km}$ $\mathrm{SE}$ ) and, therefore, distance from a source population may also be a contributing factor.

Comparisons of assemblage composition between artificial and natural reefs in the FGBNMS are confounded by the different visual sampling methods used for the two reef types. Bortone et al. (1986) compared a variety of 
methods (e.g., transect, quadrat, random count, cinetransect, still photography) and determined that estimates of community structure (i.e., proportional abundances) were similar among visual methods, but some methods provided more information in terms of species number and numbers of individuals. Other studies have demonstrated that qualitative descriptions of fauna were similar among different visual methods while quantitative estimates of density were not always comparable (Sanderson and Solonsky 1986; Thresher and Gunn 1986). When assessing community structure the most critical aspects of any method are the area surveyed (e.g., width of transect, radius of quadrat) and observation time (Sale and Sharp 1983; Fowler 1987; Bortone and Kimmel 1991), rather than the type of visual method used (Bortone et al. 1986). In this study, the dimensions of transects and quadrats, and the time spent surveying on each reef during the September sampling period were similar. Thus, despite the potential for the comparison between artificial and natural reefs to be confounded, visual methods used in this study appear adequate to delineate major differences in assemblage composition.

Within the artificial reef assemblage, species-specific patterns and associations consistently occur. The most salient spatial feature is the separation of surface dwellers from the remaining taxa in the assemblage. Although certain taxa preferred the upper waters, relative abundance and species diversity on the artificial reef were highest in the two deeper zones. These trends appear related to the influence of habitat complexity on community structure (e.g., Higo et al. 1980; Buckley 1982; Roberts and Ormond 1987; Hixon and Beets 1989; Bohnsack et al. 1991). Positive relationships between habitat complexity and both numbers of individuals and numbers of species have been reported on artificial (Chang et al. 1977; Shulman 1984; Chandler et al. 1985; Gorham and Alevizon 1989) and natural reefs (Roberts and Ormond 1987; McClanahan 1994). Similarly, our results demonstrate that the relative abundance and diversity of fishes on the platform were correlated positively with substrate complexity, both rugosity and degree of fouling. Moreover, depth-related variation in habitat complexity was measured on the platform ( $0-40 \mathrm{~m}$ depth) and maximum values were observed from 12 to $24 \mathrm{~m}$ where diversity and abundance were highest.

In addition to spatial patterns of association, temporal variation in the structure and composition of the reef fish assemblage at the platform was observed. Diel patterns were characterized by marked reductions in species abundance at night with no apparent day-night changeover of assemblages. The lack of a conspicuous day-night changeover appears to result from the scarcity of typically nocturnal species (e.g., apogonids and holocentrids; Collette and Talbot 1972; Hobson 1991). Diel activity patterns displayed by reef fishes associated with the platform appear to be related to their foraging strategy. Diurnally active demersal and midwater planktivores, including the pomacentrids and labrids, were rarely observed at night. These taxa, generally regarded as visual feeders (Hobson 1975), appear to restrict feeding to diurnal hours and seek cover at night. Diurnally active herbivores and omnivores on the platform included acanthurids and scarids. Highly active foraging groups possibly increased diurnal presence of these species. At night, all daytime herbivores and omnivores were either completely absent or greatly reduced in number. Thus, twilight cover-seeking behavior (Dubin and Baker 1982) and nocturnal inactivity appear responsible for observed nighttime reductions.

Apart from cover-seeking behavior, twilight movements also contributed to differences in diel abundances. Sphyraenids, which often form small groups during the day, moved individually outside the platform at night probably to feed on fishes attracted to the artificial light provided by the platform. Similar nocturnal behaviors have been reported in the Florida Keys (Starck and Davis 1966). In contrast, movement of kyphosids into the confines of the jacket structure was probably an antipredator tactic and indirectly the result of nocturnal feeding activity by predators. We observed Carcharhinus falciformis and Sphyraena barracuda cruising the perimeter of the platform at night feeding on kyphosids straying outside the protection of the jacket structure. Additional evidence of this apparent antipredator behavior comes from differences in day-night shoaling behavior. During the day, kyphosids form a number of small groups both inside and outside the platform. At night, the smaller groups combine to form large shoals inside the confines of the structure which potentially leads to increased protection (Pitcher and Parrish 1986).

Seasonal patterns in relative abundance were observed on the artificial reef and appear to be related to recruitment pulses. In general, species showing significant seasonal changes showed highest abundance during the September survey which was characterized by a threefold increase in the number of juveniles. In fact, juveniles, which were comprised primarily of pomacentrids, labrids, and scarids accounted for nearly $50 \%$ of all reef-dependent fishes. Peak recruitment in September is consistent with results from ichthyoplankton surveys in the Gulf of Mexico. McGowan (1985) reported that larval abundances for labrids and scarids at the FGBNMS were significantly higher during the fall. Pomacentrids were also collected by McGowan in the fall, but limited collections prevented statistical testing. Thus, early fall appears to represent a critical recruitment period for many dominant reef-dependent species inhabiting artificial and natural reefs in the FGBNMS.

Acknowledgements. We thank C. Adams, C. Beaver, G. Bunch, J. Childs, D. Henney, D. Hickerson, T. Sebastian, B. Semmens, D. Semmens, and L. Whaylen for providing essential field assistance. L. Fuiman, J. Kaldy and two anonymous reviewers made constructive comments on drafts of the manuscript. K. Binney, P. Pickering, and C. Pratt provided technical assistance. A special thanks to S. Gittings (Manager, FGBNMS), the Gulf of Mexico Foundation, Continental Shelf Association, and Rinn Boats Inc. for assisting on various aspects of this project. We are grateful to The Center for Coastal Studies and The Flower Gardens Ocean Research Program in cooperation with Mobile Exploration and Producing U.S. Inc. for providing all at sea logistical support on Mobile HI-A389A; Clyde Jones, John Reeves, and Hector Gutierrez were invaluable. Additional funding was provided, in part, by a grant from the National Fish and Wildlife Foundation (94-201) to C.V.P. and fellowships (E.J. Lund; Julian C. Barton) to J.R.R. This is contribution 970 of the University of Texas at Austin, Marine Science Institute. 


\section{References}

Adams C (1995) Species composition, abundance, and depth zonation of sponges (Phylum Porifera) on an outer continental shelf gas production platform, northwestern Gulf of Mexico. MSc Thesis, Texas A\&M University-Corpus Christi

Bohnsack JA, Bannerot SP (1986) A stationary visual technique for quantitatively assessing community structure of coral reef fishes. NOAA Tech Rep NMFS $41: 1-15$

Bohnsack JA, Johnson DL, Ambrose RF (1991) Ecology of artificial reef habitats and fishes. In: Seaman W Jr, Sprague LM (eds) Artificial habitats for marine and freshwater fisheries. Academic Press, San Diego, pp 61-107

Bortone SA, Kimmel JJ (1991) Environmental assessment and monitoring of artificial habitats. In: Seaman W Jr, Sprague LM (eds) Artificial habitats for marine and freshwater fisheries. Academic Press, San Diego, pp 177-236

Bortone SA, Hastings RW, Oglesby JL (1986) Quantification of reef fish assemblages: a comparison of several in situ methods. Northeast Gulf Sci $8: 1-22$

Bright TJ, Cashman CW (1974) Fishes. In: Bright TJ, Pequegnat LH (eds) Biota of the West Flower Garden Bank. Gulf Publishing, Houston, pp 339-409

Brock RE (1982) A critique of the visual census method for assessing coral reef fish populations. Bull Mar Sci 32:269-276

Buckley RM (1982) Marine habitat enhancement and urban recreational fishing in Washington. Mar Fish Rev 44:28-37

Chandler CR, Sanders RM Jr, Landry AM Jr (1985) Effects of three substrate variables on two artificial reef fish communities. Bull Mar Sci 37:129-142

Chang K, Lee SC, Shao KT (1977) Evaluation of artificial reef efficiency based on the studies of model reef fish community installed in northern Taiwan. Bull Inst Sool, Acad Sin 16:23-36

Choat JH (1991) The biology of herbivorous fishes on coral reefs. In: Sale PF (ed) The ecology of fishes on coral reefs. Academic Press, San Diego, pp 120-155

Collette BB, Talbot FH (1972) Activity patterns of coral reef fishes with emphasis on nocturnal-diurnal changeover. Bull Nat Hist Mus LA Co 14: $98-124$

Dennis GD, Bright TJ (1988) Reef fish assemblages on hard banks in the northwestern Gulf of Mexico. Bull Mar Sci 43:280-307

Dokken Q (1993) Flower Gardens Oceans Research Project: using offshore platforms as research stations. MTS Journal 27:45-50

Dubin RE, Baker JD (1982) Two types of cover-seeking behavior at sunset by the princess parrotfish, Scarus taeniopterus at Barbados, West Indies. Bull Mar Sci 32: 572-583

Fowler AJ (1987) The development of sampling strategies for population studies of coral reef fishes. A case study. Coral Reefs $6: 49-58$

Gallaway BJ, Lewbel GS (1982) The ecology of petroleum platforms in the northwestern Gulf of Mexico: a community profile. US Fish Wildl Serv, Off Biol Serv, Washington, DC, FWS/OBS$82 / 27,91 \mathrm{pp}$

Gorham JC, Alevizon WS (1989) Habitat complexity and the abundance of juvenile fishes residing on small scale artificial reefs. Bull Mar Sci 44:662-665

Green LE, Alevizon WS (1989) Comparative accuracies of visual assessment methods for coral reef fishes. Bull Mar Sci 44:899-912

Hastings RW, Ogren LH, Mabry MT (1976) Observations of fish fauna associated with offshore platforms in the northeastern Gulf of Mexico. Fish Bull 74:387-402

Higo N, Hashi H, Takahama I, Tabata S, Nagashima M, Sakono S, Kasmimizutara T, Yamasaki T (1980) On the fish gathering effect of the artificial reefs ascertained by the diving observation. VII. At the sea off Maskurazak City, Mem Fac Fish, Kagoshima Univ, 29:51-63

Hixon MA, Beets JP (1989) Shelter characteristics and Caribbean fish assemblages: experiments with artificial reefs. Bull Mar Sci $44: 666-680$
Hobson ES (1975) Feeding patterns among tropical reef fishes. Am Sci $63: 382-392$

Hobson ES (1991) Trophic relationships of fishes specialized to feed on zooplankters above coral reefs. In: Sale PF (ed) The ecology of fishes on coral reefs. Academic Press, San Diego, pp 69-95

Magurran AE (1988) Ecological diversity and its measurement. Princeton University Press, New Jersey

McClanahan TR (1994) Kenyan coral reef lagoon: effects of fishing, substrate complexity, and sea urchins. Coral Reefs $13: 231-241$

McClanahan TR, Shafir SH (1990) Causes and consequences of sea urchin abundance and diversity in Kenyan coral reef lagoons. Oceologia 83:362-370

McGehee MA (1994) Correspondence between assemblages of coral reef fishes and gradients of water motion, depth, and substrate size off Puerto Rico. Mar Ecol Prog Ser 105:243-255

McGowan MF (1985) Ichthyoplankton of the Flower Garden Banks, northwest Gulf of Mexico. PhD thesis, University Miami, $358 \mathrm{pp}$

Ogden JC, Gladfelter EH (1983) Coral reefs, seagrass beds and mangroves: their interaction in the coastal zones of the Caribbean. UNESCO Rep Mar Sci 23:1-130

Pitcher TJ, Parrish JK (1986) Functions of shoaling behaviour in teleosts. In: Pitcher TJ (ed) Behaviour of teleost fishes. Chapman and Hall, New York, pp 363-412

Randall JE (1983) Caribbean reef fishes. 2nd Edn, T. F. H. Publishers' Inc, New Jersey

Rezak R, Bright TJ, McGrail DW (1985) Reefs and banks of the northwestern Gulf of Mexico. John Wiley, New York

Roberts CM, Ormond RG (1987) Habitat complexity and coral reef fish diversity and abundance on Red Sea fringing reefs. Mar Ecol Prog Ser $41: 1-8$

Robertson DR (1988) Settlement and population dynamics of Abudefduf saxatilis on patch reefs in Caribbean Panama. Proc 6th Int Coral Reef Symp, 2:839-843

Rooker JR (1995) Feeding ecology of the schoolmaster snapper, Lutjanus apodus (Walbaum), from southwestern Puerto Rico. Bull Mar Sci 56:886-899

Rooker JR, Dennis GD (1991) Diel, lunar, and seasonal changes in a mangrove fish assemblage off southwestern Puerto Rico. Bull Mar Sci 49:684-698

Sale PF, Douglas WA (1981) Precision and accuracy of visual census techniques for fish assemblages on coral reef patches. Environ Biol Fish 6:333-339

Sale PF, Sharp BJ (1983) Correction for bias in visual transect censuses of coral reef fishes. Coral Reefs $2: 37-42$

Sanderson SL, Solonsky AC (1986) Comparison of rapid visual and a strip transect technique for censusing reef fish assemblages. Bull Mar Sci 39:119-129

Seaman W Jr, Lindberg WJ, Gilbert CR, Frazer TK (1989) Fish habitat provided by obsolete petroleum platforms off southern Florida. Bull Mar Sci 44:1014-1022

Shulman MJ (1984) Resource limitation and recruitment patterns in coral reef assemblage. J Exp Mar Biol Ecol 74:85-109

Starck WA (1971) Biology of the gray snapper, Lutjanus griseus,(Linneaus) in the Florida Keys. Univ Miami, Stud Trop Oceanogr 10: $12-150$

Starck WA, Davis WP (1966) Night habits of fishes of Alligator Reef, Florida. Ichthyologica 38:313-355

Thresher RE (1991) Geographic variability in the ecology of coral reef fishes: evidence, evolution, and possible implications. In: Sale PF (ed) The ecology of fishes on coral reefs. Academic Press, San Diego, pp 401-436

Thresher RE, Gunn JS (1986) Comparative analysis of visual census techniques for highly mobile, reef-associated piscivores (Carangidae). Environ Biol Fish 17:93-116

Winer BJ (1971) Statistical principles in experimental design. 2nd Edn, McGraw-Hill, New York 